
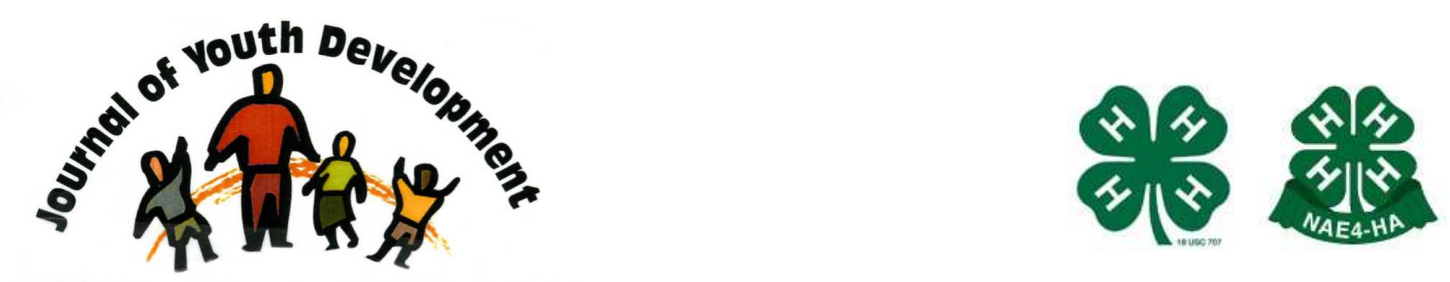

Bridging Research \& Practice

\title{
Can 4-H/FCS Curricula and Program Activities Increase Self-Esteem in At-Risk Youth Ages 8-15?
}

\author{
Walter Barker \\ 4-H Youth Development \\ University of Nevada Cooperative Extension \\ Las Vegas, NV \\ barkerw@unce.unr.edu
}

Elizabeth Curry

Family \& Consumer Sciences (FCS)

Kansas State University

Colby, Kansas

Icurry@oznet.ksu.edu 


\title{
JOURNAL OF YOUTH DEVELOPMENT \\ bridging research and practice

\section{Can 4-H/FCS Curricula and Program Activities Increase Self-Esteem in At-Risk Youth Ages 8-15?}

\author{
Walter Barker \\ University of Nevada Cooperative Extension \\ Elizabeth Curry \\ Kansas State University
}

\begin{abstract}
Nationally, 4-H programs develop educational strategies and provide opportunities for youth and adults to work in partnership as they develop life skills. This reported study looks at some curricula that enhance self-esteem in at-risk youth ages 8 to 15 . The Coopersmith Self-Esteem Instrument (CSI) measures changes in participants' self-esteem while the Massachusetts Youth Screening Instrument (MAYSI), used only at the onset of the study, alerted the staff of potential mental/emotional distress and other behavior that might require an immediate response. Girls showed a higher increase in self-esteem over the boys in the reported study.
\end{abstract}

\section{Introduction}

The ultimate goal of the national 4-H program is to develop educational strategies and provide opportunities for youth and adults to work in partnership as they develop life skills including: a positive self-concept, an enquiring mind, concern for the community, healthy interpersonal relationships and sound decision making. The program also includes other goals of helping youth become healthy, self-directing and contributing members of society. Four-H focuses mainly on positive youth development through its programs while incorporating an experiential model of learning. Self-Esteem, self-concepts are critical life skills that lead to positive outcomes. This study examines some of the curricula/program activities that lead to positive youth development, specifically as it relates to self-esteem, and seeks to find out whether these curricula/program activities do improve self-esteem in youth ages 8 to 15 . 


\section{Literature}

Social science literature is filled with research on self-esteem and behavioral changes. Several researchers have reported relationships between low self-esteem and negative or risky behavior in some youth. Kawabata and others (1999), in a study on self-esteem and smoking (risky) behavior among elementary and junior high school students, found a relationship between the two variables. Low self-esteem has been shown to be closely associated with various forms of crime and violent behaviors, and programs that foster self-esteem can contribute to reduced violence (Reasoner, 1994).

The association between self-esteem and youth behaviors has served as rationale for the creation of many self-esteem-enhancing, intervention programs. Subsequently, several researchers have, in recent years, attempted to report on the impact of different types of selfesteem enhancing programs. DiGuido and others (1997), for example, showed successes in the use of life-skill programs to promote positive self-esteem in youth. In her study on school teachers, Miller (1999) discovered an increase in self-esteem and self-confidence among students who were actively involved with an educational technology program. Kemp (1998) reported that while students with very low self-esteem showed an increase after participating in outdoor adventure, students with moderate self-esteem had significant increases and those with high self-esteem showed no or lower levels. Finally, Bijstra and Jackson, (1998) reported that social skills training decreased social anxiety, increased social activity and improved selfesteem in early adolescents.

\section{Methodology}

This study was designed to investigate the effects of youth activities on increasing self-esteem. Several control factors were built into the study design, including youth of low economic condition, social conditions with poverty, children spending time alone, children with at least one parent incarcerated, those exposed to alcohol and drug abuse, and youth with poor academic performance. The study was voluntary and each youth participant received life-skill and computer competency training as program activities to improve their self-esteem.

Kansas State 4-H Youth, in partnership with Kansas State Family and Consumer Sciences (FCS), Northwest area and associated agents, Area Juvenile Intake/Assessment Services, parents, local youth organizations and a local internet business, collaborated in the two-year study. The youth were selected from environments that were considered high risk. The purpose was to see if 4-H and FCS curricula and program activities would increase their self-esteem. Thirty (30) youth, males and females, ages 8-15 year olds, selected by the local "Big Brothers/Big Sisters" organization took part in the study. Most of those who took part in the study had at least one parent out of the home and some had at least one parent incarcerated. It was expected that attendance during participation should be $80 \%$ or greater.

The Coopersmith Self-Esteem Instrument (CSI) was used to assess the levels of self-esteem, before and at the end of the study, while the Massachusetts Youth Screening Instrument (MAYSI) instrument measured the levels of risk of the selected youth participants at the onset of the study. The MAYSI instrument was used only at the onset to alert the staff of potential mental/emotional distress and other behavior that might require an immediate response (Alcohol/Drug Use, Angry-Irritable, Depressed-Anxious, Somatic Complaints, Suicide Ideation, Thought Disturbance, and Traumatic). This instrument helped to guide instructors in terms of 
where to expect potential troubled youth, and when to be ready to reduce tensions arising from those who were identified.

Participants in the study were engaged in two, two-hour workshops from each set of the curriculum used. Parents, where ever possible, were encouraged to take part in each activity although many were unavailable to take part. Participants met once weekly, after school, and as much as necessary out-of-school, during the spring and summer breaks. Each participant maintained a portfolio of the different activities.

The first year of the study (Part one which is reported here) began in Spring 2004 and ended Fall 2005. A set of 4-H curricula was selected from the "National Juried Experiential Learning 4-H Youth Development Curricula," January 1999, as the foundation for the project. In addition, concepts and activities from other Family and Consumer Sciences curricula that support the curricula were used. Activities were selected from True Colors, Teambuilding, Youth Leadership, Communication (fun skill building), Environmental Science (Junior Master Gardener, 2001), Youth and Adults working together (Moving Ahead), Financial Management (Money \$ense for Kids), Anger Management (Rethink Anger), social interaction (area county fairs and day camps) and Understanding Computers (camp Yahoo). Activities were customized with pieces from multiple curricula. Participants, for the first time, were given an opportunity to attend several local county fairs and interact with other $4-\mathrm{H}$ youth. These curricula and program activities were used to develop life skills such as teamwork, temperament clarification, communication, leadership, and sound decision-making and technological skills.

Data collection and analysis included observation, portfolio analysis, interview analysis, and the pre and post evaluation of the CSI instrument to measure participant's self-esteem. Each participant maintained a portfolio that included summaries of what they did, what they learned, and how they would use what they learned in their home, in school, with their peers, and in the community where they lived. Portfolios and interview analysis were analyzed on the reflective changes which occurred as a result of the program activities. The MAYSI instrument, which they completed only at the onset, was analyzed to identify possible risk behaviors arising from drug and alcohol use, angry/irritable responses, depressed or anxious feeling, somatic complaints, suicide ideation, thought disturbances, or traumatic experiences. The Coopersmith Self-Esteem (CSI) was used before and after the program activities. Both instruments have established validity.

\section{Results}

General observation showed that youth participants enjoyed the program activities and looked forward to attending. Even where there were some absentees, for sometimes uncontrolled circumstances, those affected by it were eager to seek out information during their absence. Several positive comments, such as "this is awesome, "were frequently heard by youth and adults as well.

Portfolios revealed very little, perhaps because of the level of writing skills exhibited by those taking part. However, interviews with participants, parents and volunteers showed very positive remarks.

The results of the MAYSI evaluation (Table 1) were very useful. It alerted instructors of potential mental/emotional distress and other behavior problems from the caution levels and provided information while working with some participants. It also can be used to develop 
ideas of how to provide greater positive environments. Observations reported by some instructors, without their knowledge of the purpose and results of the findings of the MAYSI instrument, corroborated the value of the instrument.

Table 1

Results of the MAYSI Evaluation

\begin{tabular}{|c|c|c|c|c|c|c|}
\hline INDIVIDUALS & $\begin{array}{l}\text { ALCOHOL/ } \\
\text { DRUG USE } \\
\text { Caution }=4-6 \\
\text { Cut off }=8\end{array}$ & $\begin{array}{l}\text { ANGRY/ } \\
\text { IRRITABLE } \\
\text { Caution }=5-7 \\
\text { Cut off }=9\end{array}$ & $\begin{array}{l}\text { DEPRESSED/ } \\
\text { ANXIOUS } \\
\text { Caution }=3-5 \\
\text { Cut off }=9\end{array}$ & $\begin{array}{l}\text { SOMATIC } \\
\text { COMPLAINTS } \\
\text { Caution }=3-4 \\
\text { Cut off }=6\end{array}$ & $\begin{array}{l}\text { SUICIDE } \\
\text { IDEATION } \\
\text { Caution }=2 \\
\text { Cut off }=5\end{array}$ & $\begin{array}{l}\text { THOUGHT } \\
\text { DISTURBED } \\
\text { Caution }=1 \\
\text { Cut off }=5 \\
\text { (B) }\end{array}$ \\
\hline \multicolumn{7}{|l|}{ Males } \\
\hline$\# 82(\mathrm{M}, \mathrm{H})$ & 0 & 3 & 1 & 2 & 0 & 0 \\
\hline$\# 67(\mathrm{M}, \mathrm{H})$ & 0 & 0 & 3* & 0 & 0 & $1^{*}$ \\
\hline$\# 63(\mathrm{M}, \mathrm{H})$ & 0 & 1 & 1 & 2 & 0 & 0 \\
\hline$\# 37(M, W)$ & 0 & 8* & 1 & 1 & 0 & 0 \\
\hline$\# 76(\mathrm{M}, \mathrm{W})$ & 0 & 8 & $8^{*}$ & 6* & 4* & 3* \\
\hline$\# 1(M, H)$ & 0 & 3 & 1 & 4* & 0 & 0 \\
\hline$\# 29(M, W)$ & 0 & 0 & 0 & 0 & 0 & 0 \\
\hline$\# 28(M, W)$ & 0 & 9* & $7 *$ & $5 *$ & $5 *$ & $3 *$ \\
\hline$\# B(M, W)$ & 0 & 1 & 1 & 1 & 0 & 0 \\
\hline \multicolumn{7}{|l|}{ Females } \\
\hline$\# A(F, W)$ & 0 & $8^{*}$ & 2 & 0 & 1 & 0 \\
\hline \#93 $(F, W)$ & 0 & 7* & $5^{*}$ & 3 & $5 *$ & 0 \\
\hline$\# 97(F, W)$ & 0 & 0 & 2 & 0 & 0 & 0 \\
\hline$\# 86(\mathrm{~F}, \mathrm{~W})$ & 0 & 0 & 0 & 3 & 0 & 0 \\
\hline$\# 32(F, W)$ & 0 & 2 & 0 & 1 & 0 & 0 \\
\hline$\# 21(\mathrm{~F}, \mathrm{~W})$ & 0 & $8^{*}$ & $7 *$ & $5 *$ & 4* & 0 \\
\hline$\# 5(F, W)$ & 0 & 2 & 3 & 2 & 0 & 0 \\
\hline$\# 31(F, B)$ & 0 & $6 *$ & $5 *$ & $6 *$ & 1 & 0 \\
\hline$\# 12(F, W)$ & 0 & 4 & 3 & 2 & 0 & 0 \\
\hline$\# 95(F, W)$ & 0 & $6 *$ & 3 & 3 & 1 & 0 \\
\hline \# $94(F, W)$ & 0 & 1 & 2 & 2 & 0 & 0 \\
\hline
\end{tabular}

${ }^{*}$ Caution: to alert the staff of potential mental/emotional distress and other behavior of participants that might require an immediate response 
The results of the CSI (Tables 2 and 3) showed increases in self-esteem in those participating in the study, in both male and females. Girls, however, showed a higher increase in self-esteem over the boys. Overall, eighty percent (80\%) of the total participants showed an increase in self-esteem

Table 2

Results of Self-Esteem (Pre-test/post-test scores) of Males in the study

\begin{tabular}{|l|l|l|l|l|l|}
\hline $\begin{array}{l}\text { INDIVIDUAL } \\
\text { (Males) }\end{array}$ & $\begin{array}{l}\text { PRE- } \\
\text { TEST }\end{array}$ & $\begin{array}{l}\text { POST } \\
\text { TEST }\end{array}$ & \multicolumn{2}{l|}{ CHANGE/\% CHANGE } & $\begin{array}{l}\text { CHRONBA } \\
\text { CH's } \\
\text { Alpha }\end{array}$ \\
\hline$\# 1$ & 16 & 18 & 2 & 5 & 0.72 \\
\hline$\# 82$ & 21 & 22 & 1 & 2 & 0.72 \\
\hline$\# 63$ & 26 & 26 & & 0 & 0.72 \\
\hline$\# 67$ & 37 & 39 & 2 & 2 & 0.72 \\
\hline$\# 37$ & 36 & 38 & 2 & 2 & 0.72 \\
\hline$\# 26$ & 28 & 29 & 1 & 1 & 0.72 \\
\hline$\# 76$ & 16 & 18 & 2 & 5 & 0.72 \\
\hline$\# 29$ & 29 & 31 & 2 & 3 & 0.72 \\
\hline$\# 28$ & 15 & 18 & 3 & 9 & 0.72 \\
\hline
\end{tabular}

Table 3

Results of Self-Esteem (Pre-test/post-test scores) of Females in the study

\begin{tabular}{|l|l|l|l|l|l|}
\hline $\begin{array}{l}\text { INDIVIDUAL } \\
\text { (Females) }\end{array}$ & $\begin{array}{l}\text { PRE- } \\
\text { TEST }\end{array}$ & $\begin{array}{l}\text { POST } \\
\text { TEST }\end{array}$ & \multicolumn{2}{l|}{ CHANGE / \% CHANGE } & $\begin{array}{l}\text { CHRONBA } \\
\text { Alpha }\end{array}$ \\
\hline$\# 93$ & 26 & 29 & 3 & 5 & 0.71 \\
\hline$\# 94$ & 43 & 43 & & 0 & 0.71 \\
\hline$\# 31$ & 20 & 23 & 3 & 6 & 0.71 \\
\hline$\# 32$ & 44 & 45 & 1 & 1 & 0.71 \\
\hline$\# 95$ & 42 & 43 & 1 & 1 & 0.71 \\
\hline$\# 12$ & 31 & 31 & & 0 & 0.71 \\
\hline$\# 8$ & 39 & 40 & 1 & 1 & 0.71 \\
\hline$\# 86$ & 38 & 39 & 1 & 1 & 0.71 \\
\hline$\# 97$ & 37 & 37 & & 0 & 0.71 \\
\hline$\# 5$ & 35 & 35 & & 0 & 0.71 \\
\hline$\# 21$ & 25 & 26 & 1 & 1 & 0.71 \\
\hline
\end{tabular}




\section{Implications:}

Based on the results, it appears that certain 4- $\mathrm{H}$ and FCS curricula, delivered in certain environments and to youth between ages 8 and 15 years of age does contribute to an increase of self-esteem in youth exposed to risky environments. There should be a caution, however, that this is a preliminary study, and continued replications of these results can help to validate the effect of certain 4-H and FCS curricula, along with activities on increasing the self-esteem in youth.

The MAYSI instrument is used extensively in juvenile rehabilitation systems and is used to classify and place youth into behavioral categories (Stewart \& Trupin, 2003). The instrument is not a diagnostic tool, rather a risk assessment of estimating a youth's likelihood of displaying risky behaviors when exposed in program activities. It provides a way to anticipate the behavioral change, and to provide an environment to offset the behavior. The findings from this study provide support for the importance of identifying the likelihood of risky behaviors with youth early in a program. When youth professionals identify risk behaviors such as having a parent incarcerated or exposure to alcohol and drug abuse, they could provide these youth with additional assistance that could help them achieve more positive outcomes and increase their life skill development. In addition, attention could be focused on positive approaches to learning rather than an emphasis on consequences, placement and intervention, increasing again the likelihood of positive behavioral change and outcomes. Of course, caution must be exercised not to share such assessments with other youth engaged in the learning environment. In addition, there is a need for additional research of the MAYSI instrument to see if there are differences among race/ethnicity and gender.

Based on the findings of this study, it also appears that the activities included in these type of curricula help improve the reported self-esteem of youth when they get involved in such programs. This seems to be particularly true for females, which reinforces the importance of such programs for young women, not just focusing primarily on young men. When youth do get involved, these programs provide opportunities to develop life skills beyond what ever environment they experience.

Further research is encouraged. Examples for potential studies include Would Self-Esteem decline over time with non-continuance of the use of 4-H \& FCS curricula and program activities? And would continuous use of 4-H \& FCS Curricula \& Program Activities continuously increase Self-Esteem?

\section{References}

Bijstra, J., \& Jackson, S. (1998). Social Skills Training with Early Adolescents: Effects on Social Skills, Well-being, Self-esteem and Coping. European Journal of Education; v13 n4 p569-583.

Coopersmith, S., Self-Esteem Inventories (S.E.I) Mind Garden Inc. www.mindgarden.com

Curry, L., \& Young, C. (1999). Rethink - An Anger Management Program to Help Professionals Work with Parents and Teens. Kansas State University.

DiGuido, D., \& Others. (1997). The Positive Interaction Strategies. Action Research Project, Saint Xavier University. ED410038. 
Grisso, T., \& Barnum R. (2003). Massachusetts Youth Screening Instrument. http://www.prpress.com/books/maysi2.html

Junior Master Gardener. (2001). Health and Nutrition from the Garden, www.jmgkids.com

Kawabata, T. \& Others. (1999). Relationship between Self-Esteem and Smoking Behavior among Japanese Early Adolescents: Initial Results from a Three Year Study. Journal of School Health; v69 n7 p280-84.

Kemp, T. (1998). Panacea or Poison? Building Self-Esteem through Adventure Experiences. Exploring Boundaries of Adventure Therapy: International Perspectives. Proceedings of the International Adventure Therapy Conference. ED424053.

McFarland, M., \& Others. Moving Ahead Together. U. S. Department of Agriculture; U.S. Army, Community \& Family Support Center, Child \& Youth Services, \& Kansas State University Cooperative Extension.

Miller, B. (1999). Opinions of Teachers Regarding the Effects of Educational Technology in Elementary Classroom. Bachelor's Research paper. ED439680.

Reasoner, R.W. (1994). Self-Esteem as an Antidote to Crime and Violence. National Council for Self-Esteem. ED373281.

Wargin, F., \& Levine, M. (2000). Camp Yahoo- What Everyone should know about the internet. Creative Media application Inc. First Edition.

(C) Copyright of Journal of Youth Development $~$ Bridging Research and Practice. Content may not be copied or emailed to multiple sites or posted to a listserv without copyright holder's express written permission. However, users may print, download or email articles for individual use. 